\author{
YI LIJUN \\ (D) https://orcid.org/0000-0003-1589-1961 \\ Pekiński Uniwersytet Języków Obcych \\ (Beijing Foreign Studies University) \\ Pekin \\ ZHAO ZHEN \\ (iD) https://orcid.org/0000-0001-7313-9538 \\ Pekiński Uniwersytet Języków Obcych \\ (Beijing Foreign Studies University) \\ Pekin
}

\title{
O wierności
}

\section{O pracy nad przekładem tekstów Olgi Tokarczuk z Yi Lijun - tłumaczką literatury polskiej na język chiński - rozmawia Zhao Zhen}

On fidelity. Interview with Yi Lijun, translator of Polish literature into Chinese, on translating Olga Tokarczuk texts - by Zhao Zhen

\begin{abstract}
Translations into Chinese by Professor Yi Lijun, a distinguished translator of Polish literature, include the most popular books by the most recent Nobel Prize winner Olga Tokarczuk: Primeval and Other Times and House of Day, House of Night. During the interview, the Professor shares, for the first time, her experiences and interesting stories that happened between the translator and the writer. This allows us to find out what brought the writer's novels success among Chinese readers.
\end{abstract}

Key words: Olga Tokarczuk, Yi Lijun, translations of Polish literature into Chinese

Zhao Zhen: W jakich okolicznościach poznała Pani Profesor Olgę Tokarczuk?

Yi Lijun: Z jej twórczością zetknęłam się po raz pierwszy około 2000 roku, do tłumaczenia przystapiłam trzy lata później, natomiast pierwszy raz spotkałam ją osobiście w 2008 roku. Olga Tokarczuk przyjechała wtedy do Pekinu na zaproszenie Stowarzyszenia Pisarzy Chińskich. Miałam nawet 
okazję gościć ją u siebie w domu. Kolejny raz spotkałam ją w 2012 roku w Krakowie na Światowym Kongresie Tłumaczy Literatury Polskiej. Lączy nas przyjaźń literacka, utrzymujemy ze sobą kontakt już od wielu lat.

Z.Z.: Jaka osobą jest według Pani Profesor Olga Tokarczuk? Jakie uczucia wiąże Pani Profesor z jej osobą?

Y.L.: Mimo że Olga bezsprzecznie jest jedną z najbardziej wpływowych współczesnych polskich autorek, to zachowuje się bardzo naturalnie, w jej sposobie bycia nie ma niczego z postawy „,wielkich pisarzy”. Jest w wieku mojej córki, ma pogodny charakter, posiada sporą wiedzę na temat Chin, jest niezwykle serdeczna oraz bardzo ciekawa świata. Pamiętam, że gdy Tokarczuk przyjechała do Pekinu w marcu 2008 roku, złożyła wówczas także wizytę na Wydziale Języków i Kultur Europejskich na Pekińskim Uniwersytecie Języków Obcych (PUJO). Bardzo chciała poznać mnie i mojego męża, gdyż wiedziała, że to my tłumaczyliśmy Prawiek $i$ inne czasy oraz Dom džienny, dom nocny. Niezmiernie się ucieszyła na nasz widok. Przy okazji wygłosiła też wykład na naszym Wydziale. Po prelekcji została zaproszona na uroczysty obiad przez władze uczelni, na którym my także byliśmy obecni. Później zaprosiliśmy ją do naszego domu, gdzie rozmawialiśmy dwie i pół godziny. Gdy dowiedziała się, że jest w wieku naszej córki, natychmiast zażartowała: „Moglibyście być moimi chińskimi rodzicami!”. Odpowiedziałam jej wtedy: „Wszyscy ojcowie i matki na całym świecie by nam zazdrościli, gdybyśmy mieli taką córkę jak ty!”. Podczas tamtego spotkania naprawdę dało się odczuć taką bliskość jak w prawdziwej rodzinie. Śmialiśmy się bez przerwy. Zadawaliśmy jej też pytania, na przykład prosząc o wyjaśnienie bardziej zawiłych fragmentów jej powieści, by upewnić się, czy nie zrozumieliśmy ich opacznie. Odparła: „Zrozumieliście absolutnie prawidłowo, dokładnie o to mi chodziło”. Naturalnie, jej odpowiedź bardzo nas uspokoiła. Rozmawialiśmy wtedy na rozmaite tematy, o Polsce i o Chinach, o literaturze i o życiu. Opowiadała o swoich spostrzeżeniach po przybyciu do Chin, prosząc nas o wyjaśnienie kwestii, których nie do końca rozumiała, a my staraliśmy się rozwiewać wszystkie jej wątpliwości. $\mathrm{Na}$ koniec zrobiliśmy sobie razem pamiątkowe zdjęcie. Chcieliśmy zaprosić Olgę Tokarczuk wraz z towarzyszącymi jej osobami na wspólną kolację, lecz musiała odmówić, gdyż tego wieczora miała zaplanowane jeszcze inne spotkania.

Z.Z.: Olgę Tokarczuk zaskoczyła zapewne wiadomość, że w Chinach ma tak wielkie grono czytelników. 
Y.L.: Rzeczywiście, nie zdawała sobie sprawy, że jej powieści są w Chinach aż tak popularne. Bardzo się ucieszyła, bo - nie ma co ukrywać - nie jest łatwo znaleźć ludzi mogacych nas zrozumieć tak daleko od domu.

Pewnego razu zapytała mnie, w jakim nakładzie ukazały się jej książki w Chinach. Odparłam, że nie jestem pewna, ale przypuszczam, że nakład był niewielki. „Pewnie dlatego, że moje książki są kiepskie?” - zapytała. „To nie z tego powodu” - powiedziałam i wyjaśniłam, ze przekłady literatury zazwyczaj wydaje się w bardzo ograniczonej liczbie. Olga nie mogła zrozumieć, dlaczego w tak dużym kraju drukuje się tak mało książek. Oczywiście, teraz się to zmieniło. Literacka Nagroda Nobla cieszy się w Chinach znakomitą reputacją, więc gdy tylko ogłoszono nazwiska laureatów, wydawnictwa natychmiast wykupiły całość praw autorskich.

Z.Z.: Czy mogłaby Pani Profesor przytoczyć przebieg jakiejś ciekawej rozmowy z pisarką?

Y.L.: Ja i mój mąż mamy z Olgą wiele wspólnych tematów do rozmów, więc gdy przyszła do nas w odwiedziny, przegadaliśmy z nią całe popołudnie. Rozmawialiśmy o wszystkim, lecz mając na uwadze dzielącą nas różnicę wieku, staraliśmy się nie podejmować zbyt prywatnych tematów. Ona mimo wszystko nie traktowała mnie jak kogoś starszego od siebie. Dyskutowaliśmy zarówno o książkach, jak i o sprawach niemających z nimi żadnego związku.

Nie wiedziałam zbyt wiele o jej życiu prywatnym, ale nie wypadało mi też pytać. Ostatecznie jestem od niej znacznie starsza, Olga koniec końców jest rówieśniczką mojej córki.

Już wtedy wszyscy (zarówno ja, jak i cała Polska) spodziewali się, że Tokarczuk zdobędzie Nobla. Gdy gościła u mnie w domu, wspomniałam, że Polska może poszczycić się już kilkoma laureatami Literackiej Nagrody Nobla i zasugerowałam, że kolejną laureatką będzie pewnie ona. Ze śmiechem odparła, bym nawet tak nie żartowała.

Później, w 2012 roku na Światowym Kongresie Tłumaczy Literatury Polskiej w Krakowie, na którym byłam wraz z mężem, towarzyszyła nam podczas obiadu. Wówczas przy stole siedział z nami również Zagajewski.

Z.Z.: Co, w opinii Pani Profesor, najbardziej pociaga chińskich czytelników w powieściach Tokarczuk?

Y.L.: Twórczość Tokarczuk przedstawia rzeczywistość w zawoalowanej formie. Jej powieści są jednocześnie fikcyjne i realistyczne - w rzeczywistości dostrzec można fikcję, a przez fikcję przebija rzeczywistość. Myślę, że Olga nie ma sobie równych wśród pisarzy współczesnych. Jej twórczo- 
ści nie da się zaliczyć ani do realizmu magicznego, ani do czystego realizmu, plasuje się gdzieś pomiędzy tymi dwoma nurtami. W swoich tekstach Olga poddaje analizie zagadnienia bardzo ogólne, np. dokąd sięgają korzenie polskiego narodu czy jakie jest miejsce człowieka w historii. Różnica między Tokarczuk a pisarzami poprzedniego pokolenia, takimi jak Miłosz, polega właśnie na sposobie, w jaki traktuje naród i historię. Mimo iż naród polski wiele wycierpiał, to ona nie szuka winnych, lecz dokłada starań, by ukazać najwspanialsze chwile w dziejach Polski. Myślę, że to bardzo wyjątkowe podejście, cechujące najnowsze pokolenie polskich pisarzy. Młodzi autorzy często umniejszają rolę historii, traktuja twórczość literacka jako formę duchowej przyjemności. Myślą nie tylko o tym, by samemu czerpać radość z pisania, dokładają też starań, by ich teksty były przystępne, nie wymagały od czytelnika wysiłku ponad jego możliwości. Czytając książki Tokarczuk, można odnieść wrażenie, jakby przyjaciel szeptał nam historię do ucha. Ale mimo tego, że miło się ich słucha, to w najsubtelniejszych detalach można odkryć głęboki sens. Dlatego naprawdę warto czytać jej książki i to czytać je nieustannie. Dla Tokarczuk początek i zakończenie są w istocie iluzja. Tworzenie opowiadań przy zastosowaniu tradycyjnej osi czasu nie jest w jej stylu, gdyż ludzka świadomość wcale tak nie funkcjonuje. Świat tworzą raczej miliony połączonych ze sobą fragmentów. Bardzo wyraźnie odzwierciedlają ten pogląd Bieguni oraz Prawiek i inne czasy.

Z.Z.: Czy tłumacząc powieści Tokarczuk, natrafiła Pani Profesor na fragmenty bardzo silnie naznaczone polską kultura, które trudno było przełożyć na język chiński?

Y.L.: Chociaż jej książki są głęboko osadzone w polskiej tradycji literackiej i polskim, społeczeństwie, to jednak z wielką gracją wyszła poza tę polskość. Chodzi o to, że pomimo iż jest polska pisarka, to wszelkie przemyślenia filozoficzne zawarte w jej twórczości odnoszą się do całej ludzkości. Jest to efekt jej wiedzy na temat ludzkiej psychiki oraz dogłębnych rozmyślań nad samą sobą. Dzięki temu możemy utożsamiać się z jej przemyśleniami, gdyż istota problemu nie zmienia się bez względu na to, gdzie jesteśmy. Gdy natrafiałam na fragment, którego wymowy sama nie byłam do końca pewna, zwracałam się z prośbą o pomoc bezpośrednio do Olgi Tokarczuk. Myślę, że największą trudność sprawiły mi fragmenty, w których pod fikcyjną warstwa nakreśloną za pomocą opisu psychologicznego skrywało się drugie dno. Mimo że pod względem językowym jest to pozornie proste, to zachowanie tych ukrytych treści w przekładzie jest niesłychanie trudne. Tokarczuk nie posługuje się w swoich powieściach prze- 
sadnie kwiecistym, aluzyjnym językiem, jak to bywa w przypadku innych autorów. Mimo to, tłumacząc jej utwory, należy zachować szczególną ostrożność, by nie zatracić w przekładzie żadnych idei w nich odzwierciedlonych. Nie może zabraknąć żadnego drobiazgu, w przeciwnym razie przepadnie cała wielka myśl, którą autorka chciała przekazać.

Z.Z.: Która z tłumaczonych powieści Tokarczuk spodobała się Pani Profesor najbardziej?

Y.L.: Najbardziej (mimo wszystko) lubię pierwszą powieść Tokarczuk, którą tłumaczyłam, czyli Prawiek $i$ inne czasy, ponieważ wtedy pierwszy raz zetknęłam się z książką tak bardzo inną od pozostałych, niesamowicie ciekawą i pociagająca. O ile z jednej strony jest to powieść całkowicie realistyczna, to z drugiej strony jest to pięknie napisana baśń dla dzieci. Innymi słowy, jest to obfitujące w mistyczne treści dzieło utrzymane w duchu realizmu. Napisane zostało językiem jednocześnie zrozumiałym i pełnym gracji, bez górnolotnych słów czy niezrozumiałych, zawiłych zdań. Pojawiające się w powieści opisy, klarowne i poetyckie, przenoszą zarówno tłumacza, jak i czytelnika do wspaniałego świata. Między liniami można co raz odczytać humor i błyskotliwość, drwinę i dowcip. Wzbudza to też zainteresowanie ze strony tłumacza. Pojawiające się w utworze nawiązania do mitów, legend czy nawet przypowieści biblijnych wzbogaciły opis postaci oraz zarysowały atmosferę otoczenia, dzięki czemu całość przesycona jest baśniowym kolorytem. To nieustanne balansowanie pomiędzy snem a jawa, prawdą a fikcją zmusza czytelnika do głębokich przemyśleń i na długo zapada w pamięć, jeśli tylko przeczyta się tę książkę dość uważnie.

Gdy zaś chodzi o Dom dzienny, dom nocny, to wydaje mi się, że jest to trudniejsza lektura od Prawieku. Na tle innych dzieł literatury polskiej lat 90. ubiegłego wieku jest to pozycja bez watpienia przełomowa. To wielowątkowa, wielowarstwowa powieść, którą tworzą dziesiątki felietonów, historii i esejów. Nie dziwi mnie wcale, że kilku polskich krytyków porównało jej książkę do barwnego płaszcza uszytego z różnokolorowych skrawków materiału. Można odnieść wrażenie, jakby było tu mniej spójności wewnętrznej niż w jej innych powieściach. To dzieło na pograniczu różnych gatunków literackich, w którym przeplatają się wszelkiego rodzaju środki retoryczne. Jest to istna hybryda najróżniejszych form literackich: od autobiografii i esejów poprzez narrację aż po epopeję czy rozprawkę czego tylko dusza zapragnie. W książce nie odnajdziemy jednego wiodącego motywu, tylko nagromadzenie rozlicznych postaci i tematów. $\mathrm{Na}$ pierwszy rzut oka trudno więc znaleźć jakiś wspólny mianownik. Rozmaite 
wątki osadzone są w różnych miejscach na osi czasu, od starożytności poprzez średniowiecze i wiek XVIII aż po czasy współczesne. Autorka zdaje się wykorzystywać całkowicie niepowiązane ze sobą epizody, łącząc je dobrowolnie niczym klocki Lego i tworząc z nich całość, której zrozumienie wymaga niemałego wysiłku. Można też na to spojrzeć jak na naszyjnik zrobiony z wielobarwnych korali. Z tych pozornie niepowiązanych ze sobą klocków i korali udało się jednak stworzyć pisarce niezwykle spójną całość. Uważny czytelnik odkryje, że wszystkie te wątki łączy postać wiejskiej kobiety. Wszelkie pojawiające się w książce historie, legendy, anegdoty oraz oceny wydarzeń czy nawet zapowiedzi losów niektórych postaci wychodzą właśnie z jej ust. W powieści bardzo ważną funkcję odgrywa także sen. Wiele przedstawionych w niej historii czy opowiastek utrzymanych jest właśnie w konwencji onirycznej. Tak naprawdę trudno wyobrazić sobie inny sposób, w jaki możliwe stałoby się zintegrowanie wydarzeń z tak wielu różnych okresów czasu w jednym utworze. W tekście odnaleźć można też sporo różnych opisów snu: sen dzienny, sen nocny, sen w sieci. Sen jest wszechobecny w tej powieści, dlatego nie byłoby bezzasadne, aby upatrywać w nim głównego bohatera utworu. Życie to sen, a sen to odbicie życia. Dom dzienny symbolizuje rzeczywistość, dom nocny natomiast przeszłość i legendy. Takie jest właśnie nasze życie.

Z.Z.: Jaką zazwyczaj obiera Pani Profesor strategię przekładową: udomowienie czy egzotyzację? Czy zdarza się, że z uwagi na czytelnika stosuje Pani Profesor różne metody tłumaczeniowe?

Y.L.: Wierność oryginałowi jest najważniejsza. Podczas tłumaczenia nie myślę nigdy o odbiorcy, ponieważ uważam, że nie wolno ingerować w tekst oryginalny tylko z uwagi na czytelnika. Jest to niedopuszczalne. Podstawowym zadaniem tłumacza jest bezstronne przełożenie tekstu oryginalnego na inny język. To czytelnik powinien przyswoić sobie tekst, gdyż tekst istnieje po to, by zaszczepić w czytelniku pewne idee. Tłumacz musi odpowiedzieć sobie jasno na dwa pytania: co zostało napisane oraz dlaczego właśnie w taki sposób. Ocenę tego, jak zostało napisane, trzeba zostawić już czytelnikowi.

Z.Z.: Jakie strategie tłumaczeniowe są według Pani Profesor najskuteczniejsze w przypadku przekładu książek Tokarczuk?

Y.L.: Zacząć należy przede wszystkim od zrozumienia samego tekstu oraz wszelkich ukrytych w nim znaczeń, dopiero później należy skrupulatnie go przetłumaczyć. Przekładam tekst tak, jak rozumiem, i jako tłumaczka nie mogę arbitralnie dodawać żadnych nowych znaczeń. Bardzo istotną cechą 
twórczości Tokarczuk są niedomówienia, dlatego przekład na język chiński musi być równie niedookreślony. Z powodu tego wyjątkowego i zarazem zwodniczego języka, charakteryzującego jej powieści, bardzo łatwo niechcący dodać coś od siebie podczas tłumaczenia. Nie możemy tego robić, inaczej przekład zatraci oryginalny sens utworu.

Żeby móc dobrze przełożyć książki Tokarczuk, należy uchwycić trzy podstawowe elementy jej twórczości: nowatorstwo, pomysłowość, wyjątkowość. Nowatorskie jest spojrzenie autorki na problem, pomysłowe wykorzystanie technik pisarskich, wyjattkowość dotyczy natomiast faktu, że jej teksty przedstawiają najniezwyklejsze elementy rzeczywistości.

Z.Z.: Czy w przekładzie potrzebne były jakieś specjalne przypisy?

Y.L.: W trakcie tłumaczenia stwierdziłam, że język, którym posługuje się Olga, jest bardzo przystępny, choć skrywa w sobie wiele znaczeń. W jej tekstach zauważalny jest zarówno wpływ psychologii, jak i kultury starożytnej Grecji - horyzonty kulturalne Olgi są niezwykle rozległe. Używając subtelnego języka i baśniowych wątków, w historii całej ludzkości autorka próbuje odnaleźć korzenie polskiego narodu oraz jego miejsce w świecie. Z tego powodu czytelnik, który chce naprawdę zrozumieć powieści Tokarczuk, musi mieć bardzo dużą wiedzę. Mimo to zastosowałam niewiele przypisów, bo - według mnie - to pójście na skróty. Przekład tekstu literackiego można zakwalifikować jako reprodukcję dzieła - nie potrzeba w nim zbyt wielu przypisów, tak jak np. w przypadku tłumaczenia artykułu z dziedziny teorii literatury.

Z.Z.: Czy tłumaczy Pani Profesor zazwyczaj bez robienia sobie dłuższych przerw?

Y.L.: Naturalnie tego typu powieści, przesycone rozważaniami filozoficznymi, tłumaczy się dużo trudniej. Przemyślenie tych wszystkich kwestii, aby uchwycić pierwotny zamiar autora, wymaga dużo czasu i energii. Olga, posługując się niezwykle lekkim, prostym językiem, przekazuje w swych utworach głębokie prawdy filozoficzne. Trzeba bardzo uważnie wczytać się w tekst, w przeciwnym razie bardzo łatwo można je przeoczyć. Gdy tylko uda się pojąć zamysł twórczy pisarki, ubranie tego wszystkiego w słowa staje się szybkie i łatwe. 
Yi Lijun - prof., Pekiński Uniwersytet Języków Obcych (Beijing Foreign Studies University), Pekin, Chińska Republika Ludowa.

Wybitna tłumaczka. W jej dorobku naukowym znajdują się takie prace, jak Literatura polska (1999) i Historia polskiej literatury powojennej (2004), a także ponad 20 artykułów naukowych. Do jej najważniejszych przekładów należą: Henryka Sienkiewicza Krzyżacy (tłum. Yi Lijun, Zhang Zhenhui, wyd. 1996), Ogniem i mieczem (tłum. Yi Lijun, Yuan Hanrong, wyd. 1997), Adama Mickiewicza Pan Tadeusz (tłum. Yi Lijun, Lin Hongliang, wyd. 1998), Dziady (tłum. Yi Lijun, Lin Hongliang, Zhang Zhenhui, wyd. 2015), Olgi Tokarczuk Prawiek i inne czasy (tłum. Yi Lijun, Yuan Hanrong, 2003), Dom dzienny, dom nocny (tłum. Yi Lijun, Yuan Hanrong, 2007) i in. Za swoją działalność otrzymała wiele nagród i odznaczeń: odznakę honorową Zasłużony dla Kultury Narodowej w 1984 roku, odznakę honorową Zasłużony dla Kultury Polskiej w 1997 roku, w 2000 roku prezydent Aleksander Kwaśniewski uhonorował ją Krzyżem Kawalerskim Orderu Zasługi Rzeczypospolitej Polskiej, w 2007 roku otrzymała tytuł doktora honoris causa Uniwersytetu Gdańskiego. W 2018 roku odebrała najbardziej prestiżową nagrodę w chińskim kręgu tłumaczy literackich za całokształt dorobku zawodowego. Jest laureatką programu Ambasador Polszczyzny w kategorii Ambasador Polszczyzny poza Granicami Kraju.

Rok 2019 okazał się rokiem niezwykłym. 10 października Akademia Szwedzka ogłosiła przyznanie Oldze Tokarczuk Literackiej Nagrody Nobla za rok 2018. To wydarzenie wywołało ogromne poruszenie w chińskich kręgach literackich, medialnych i wydawniczych oraz lawinowy wzrost zainteresowania Olgą Tokarczuk. Niemały udział w sukcesie pisarki mają tłumacze jej utworów. Prof. Yi Lijun to niedościgniona tłumaczka literatury polskiej. Już na początku XXI w. przetłumaczyła dwie powieści Tokarczuk: Prawiek $i$ inne czasy oraz Dom dzienny, dom nocny. Pani Profesor poznała Olgę Tokarczuk w 2008 roku. Okazało się, że obie doskonale się rozumieją w wielu kwestiach, dlatego utrzymują ze sobą kontakt już od dziesięciu lat. Podczas wywiadu prof. Yi Lijun bardzo często nawiązywała do tej przyjaźni, jednocześnie dzieląc się refleksjami, które snuła w trakcie tłumaczenia powieści Tokarczuk. Jest to niezwykle cenne podsumowanie kunsztu pracy łłumacza, stanowiące źródło inspiracji dla kolejnych pokoleń tłumaczy literackich.

Zhao Zhen - mgr, Pekiński Uniwersytet Języków Obcych (Beijing Foreign Studies University), Pekin, Chińska Republika Ludowa.

Absolwentka polonistyki Pekińskiego Uniwersytetu Języków Obcych. Odbyła staż językowy na Wydziale Filologicznym Uniwersytetu Śląskiego. Jest również tłumaczką. Przełożyła z polskiego na chiński książkę Lektury nadobowiązkowe Wisławy Szymborskiej, rozprawę dr hab. Magdaleny Bąk oraz kilka książek dla dzieci. Obecnie zajmuje się przede wszystkim studiami na temat Polski oraz teorią literatury.

Kontakt: GrazynaZhao@hotmail.com

Michał Kumor - mgr, Pekiński Uniwersytet Języków Obcych (Beijing Foreign Studies University), Pekin, Chińska Republika Ludowa.

Absolwent studiów licencjackich Uniwersytetu Śląskiego na kierunku filologia angielska, specjalność tłumaczeniowa z językiem chińskim. Obecnie magistrant kierunku tłumaczenia chińsko-polskie na Pekińskim Uniwersytecie Języków Obcych. 